\title{
WEBSITE WWW.GOAL.COM AS AN INSTRUCTIONAL MODEL DEVELOPMENT
}

\author{
Mariska Febrianti ${ }^{1}$, Azizatul Banat ${ }^{2}$, Arifto Juniardi ${ }^{3}$ \\ (Health Physical Education and Recreation Study Program, Teacher Training and Education Faculty, The \\ University of Dehasen Bengkulu, Indonesia) \\ mariska.febby@unived.ac.id, azizatulbanat@unived.ac.id, ariftojuniardi@gmail.com
}

\begin{abstract}
Generally someone who is said to master English or at least who can communicate is the one who masters in 4 basic skills, namely listening, speaking, reading and writing. While the problems that researchers often encounter in the field are still far beyond the basic things, namely the lack of vocabulary mastery by sports students at Dehasen University, Bengkulu. Therefore, through this study, the researchers intended to motivate sports students to learn English by developing instructional models that suitable to their characteristics. Researchers believe that utilizing this student's love for sports can arouse their enthusiasm in learning so that researchers utilize the website www.goal.com and collaborate with sports lecturers and English lecturer to develop instructional models in the form of existing English teaching materials which are then modified in accordance to characteristics of sports students. The method used in this study is $R \& D$ (Research \& Development). The results of this study are the existence of instructional model using the website www.goal.com can increases the vocabulary mastery of sports students and they are become more motivated in learning in the classroom. It can be seen from the average value of the pre-test and post-test.
\end{abstract}

Keywords: development of instructional models, sports students

\section{INTRODUCTION}

English is a universal language that acts as one of the important aspects if someone has it that can be an advantage in the work environment and in society. Along with the development of the era and globalization era, Indonesia as a developing country cannot be separated from the influence of globalization, so it must have the readiness of human resources capable of communicating in English both orally and in writing. To be able to communicate well in English there are 4 basic skills that must be mastered, namely listening, speaking, reading and writing. In mastering the four skills, a strong vocabulary mastery is needed as a basic for learning.

This vocabulary mastery has an important role as an initial foundation that must be owned by someone because it is very closely related to the four basic skills. However, researchers still find a lack of vocabulary that can be mastered by students 
even though they have studied English since the level of elementary school, junior high school and senior high school so that this has an impact to the college level (higher education) and for the world of work they will face later. Then the material delivered is still in general and not close to the surrounding environment so that it impacts on learning outcomes.

Besides that the teaching method used is still convensional that the so that it does not motivate students to learn. This can be seen in sports students at the Dehasen University, Bengkulu. The sport students in that program who have not mastered English either in oral or writing, even English has become a frightening specter for them. Not only that, the lack of motivation to study in the classroom is a consideration for sports students in determining their chosen study program. The love of sports students in various types of sports is one solution for researchers to increase motivation in learning English. Based on the observations, the English language learning material applied to sports students is still general in nature and has not been so connected with their world that teaching and learning activities still seem boring.

From the several phenomena in English learning described above, the form of this study is the development of an English instructional model through the website www.goal.com for sports students who focus on increasing vocabulary mastery. This is intended to encourage students to make the relationship of knowledge that is owned and apply it in social life as in the world of work. Based on the description of the background above, the formulation of the problem in this study is how to develop English instructional models for sports students in increasing the vocabulary mastery?.

Teaching materials are a set of materials that are arranged for learning needs both in print and using technology such as video, audio, etc. Teaching materials themselves have different definitions according to experts, Dick, Carey L. and Carey J. (2005: 7) teaching materials are also referred to as instructional materials that contain forms of learning such as instructions for instructors / instructors, student modules, Overhead Transparency (OHP), videotapes, computer-based multimedia formats and web pages for distance education. 
Whereas according to Christopher Butcher et.al. (2006: 130) teaching materials are also called learning materials in the form of visual aids such as handouts, slides / overheads consisting of text, diagrams, images and photographs and other media such as audio, video, and animation. This is also supported by Kenji Kitao and Kathleen Kitao (2009: 4) who argue that teaching materials are materials provided for learning needs that include textbooks, video and audio tapes, computer software, and visual aids.

From some expert opinions above, there are several forms of teaching materials that can support the success of teaching and learning processes in students. But in the current era of globalization, with the development of times such as sophistication in technological has an impact on students in learning. Monotonous teaching methods can influence students' interest and motivation in learning and even determine their learning outcomes. Therefore, teachersor lecturer as teaching staff must be capable and creative in developing teaching materials to motivate students and improve their learning outcomes.

According to Tomlinson (2001) the development of teaching materials or materials based on fields of study and practice. Where in the field of learning studies contains the principles and procedures for the development, application, and evaluation of learning materials. Whereas in practice, the development itself is carried out by the writer, the teacher or the student related to the source of the language to stimulate its purpose. The material developer himself writes the results of his work in the form of textbooks, or expresses opinions on the use of language.

On the other hand, Sells and Richey in Pujiati Hanip (2015) state that development is a process of translating designs into physical forms that are part of learning technology. The technology coverage used in the development concept is divided into four categories, namely: (a) printing technology, (b) audio-visual technology, (c) technology that uses computers, and (d) integrated technology. Basically development activities can be explained through learning strategies, messages that contain information and physical forms of hardware, software, and learning materials. 
From the two expert above, it can be concluded that the development of material or teaching materials in the form of development that has gone through several stages and has been tested and then made into physical form in the form of software, hardware or learning materials. In carrying out the development activities, Dick, Carey L. and Carey J. (2005: 6) explain some important considerations that need to be understood first, among others: (1) identifying learning objectives (competency standards), (2) conducting learning analysis, (3) analyzing students and context, (4) writing specific instructional objectives (basic competencies), (5) developing assessment instruments, (6) developing learning strategies, (7) developing and selecting learning materials, (8) designing and doing evaluation, (9) make revisions, and (10) design and conduct summative evaluations. Whereas Latif (2012) argues that there is an interactive learning process with stages that are effective in implementing a product or strategy and learning method, media and teaching materials, namely the ADDIE model. The ADDIE (Analysis Design Development Implementation Evaluations) model begins with the concept of Instructional Design Models and Theories for the US Army in 1950. The ADDIE Model is designed to ensure that the learners will achieve the goals and objectives of the learning purposes. It also allows the evaluation of students' needs and provides simple procedure to design and develop materials.

\section{English Learning}

Sanjaya (2005: 7) defines learning as information and environmental settings to facilitate the learning process including selection, preparation, and delivery of information in an appropriate manner to interact with students in the environment. From the explanation above, it can be concluded that good and effective learning should focus on building students' knowledge that is closer to their environment in order to provide individual experience.

English is one of the adaptive subjects taught to improve students' language skills. The focus of mastery of this language is as a tool for communicating both verbally and in writing that is used to convey information, thoughts and feelings. According to Tusino and Dewi (2016) states that communication skills intended here are discourse 
skills namely the ability to understand and or produce oral or written texts contained in four language skills namely listening, speaking, reading and writing. At present English learning has not yet reached its basic goal, namely as a tool for communication. Therefore it is necessary to develop a learnings model in the form of teaching material in order to motivate learning and improve students' communication skills in English.

\section{Website www.goal.com}

Website www.goal.com is an online website that contains the latest news about football and matches currently held and has several language versions. English is one of the languages used on this website in broadcasting its news. Therefore researchers want to use this website as a source of learning English for sports students because this website meets the requirements of the concept / approach to contextual teaching and learning (CTL) to modify English learning material that is close to the environment / real life sports students to encourage students make the relationship of knowledge possessed and apply it in life in order to motivate them in learning and improve their vocabulary mastery..

\section{METHODOLOGY}

The method used in this study is Research \& Development which carried out in the classroom and an assessment of student learning motivation. According to Latif (2012) R \& D is one of the research designs based on problems in the classroom in the form of development of educational products that have been expertly validated and tested in the field.

This study aims to develop or modify the form of existing English learning material and then make it into a learning media by involving technological sophistication that is in accordance with the characteristics of sports students. In this study, researchers adopted the ADDIE Model (Prawiradilaga, 2009). Where the extension of the ADDIE model is (Analysis) analysis, (Design) design, 
(Development) development, (Implementation) implementation and (Evaluation) evaluation.

In the first stage of the ADDIE Model according to Prawiradilaga (2009) it consists of two stages, namely: performance analysis and needs analysis. In the analysis of performance researchers clarify whether there are problems in the learning process and find the right solution to the problem. For example: the low achievement motivation, saturation, or boredom in learning requires a bail quality improvement solution in terms of delivery methods or learning media and media. Furthermore, there is a needs analysis which is a step that is needed to determine the abilities or competencies that students need to learn to improve their vocabulary mastery. This can be done if the learning program is considered as a solution to the learning problems being faced.

The second stage is the design which is the second step of the ADDIE Model. At this stage consists of several steps, namely:

a. The core of the analysis step is to study the problem then find alternative solutions which are then identified as needed.

b. Then see the learning experience that has been owned by students during the learning activities.

c. Steps that must be able to answer questions, whether the learning program can overcome the problem of the gap in the ability of students in terms of vocabulary mastery.

The third stage is development. This development step includes activities to make, modify teaching materials. In other words it includes choosing activities, determining methods, media and learning strategies that are suitable for use in conveying material or substance of the program. In addition, in this stage there are two main objectives that need to be achieved, namely: making or revising the teaching material that will be used to achieve the learning objectives that have been formulated previously and choosing the best media or combination of media that will be used to achieve learning goals where in this study using ICT in the form of a website www.goal.com. 
Implementation or delivery of learning material is the fourth step of the ADDIE Model learning system design model. The main purpose of this step is to achieve goals or competencies, namely by finding solutions to problems that have been found, finally ensuring competencies or knowledge of skills, and attitudes needed. In this study focuses on strengthening vocabulary.

The final step of this model is an evaluation in the design of the ADDIE learning system. Evaluation is a process carried out to provide value to the learning program. The implementation of the ADDIE model in a systematic learning system is expected to help a good program designer, teacher, and instructor to create an effective, efficient and interesting learning program for students. The ADDIE development model is an effective and efficient learning planning model and the process is interactive, where the evaluation results of each phase can bring the development of learning to the previous phase. The end result of a phase is the initial product for the next phase. Stages in the ADDIE model.

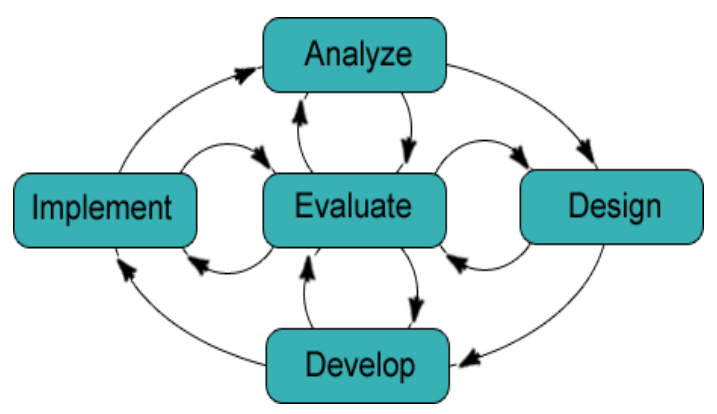

Figure 1. Addie Model (Prawiradilaga, 2009)

\section{Subject and Time of Research}

The subjects in this study were sports students at Dehasen University, Bengkulu, namely students in the second semester. The time of the study (data collection) was carried out in January-June 2019. Where the population in this study were sports students in the second semester who took Professional English courses. While the sample in this study amounted to 35 people. Sampling in this study using purposive sampling technique. Where according to Sugiyono (2016) purposive sampling is a 
technique for determining research samples with certain considerations so that the data obtained later can be more representative.

\section{Data Analysis Technique}

Data analysis techniques that will be used in this study are carried out using two approaches, namely qualitative and quantitative. Qualitative data analysis is by analyzing data from the validation (assessment) of experts (experts) and user models, in order to improve the English instructional model. In the analysis of quantitative data obtained through the assessment instrument, the mean mean score is then converted to qualitative data, and finally described. Based on the results of the description serve as the basis for assessing the quality of the model developed along with the tools and guidelines.

\section{RESULT/FINDINGS}

Sports students generally like activities that are outdoors, they are very identical to things that involve physical strength. In fact, sometimes there is a paradigm that this sports student is only good at sports and weak in learning in the field of theory. This is the main problem that researchers have encountered in the field and is a very interesting thing to be examined. One type of learning in the form of theory is English, where there are always even these subjects that they always meet at school from the elementary level to the university, but this is the ability they are the least mastered. For that, after the researcher found the problem, the researcher then used the ADDIE Model to get a solution.

In developing an English instructional model for sports students, researchers use the ADDIE Model, which has several stages, namely analysis, design, development, implementation and evaluation. In the first stage, researchers conduct observations or observations on sports students in the teaching and learning process in the classroom. Where they still use conventional methods, namely in the form of material delivery by lecturers in front of the class with the help of modules as learning media. In the results of this observation it was found that students were less enthusiastic and motivated in 
learning English. This can be seen when the lecturer asks questions or asks to mention examples of nouns (Noun) in a singular or plural form, there are still many students who are silent without giving responses or answers to the lecturer. Where in practice in the module itself there are explanations, concepts and examples of the subject matter. Students are too lazy to open a module they already have or they don't understand what the English language module contains. This is what is called performance analysis, one part of the analysis phase.

The next part is an analysis of the need to determine abilities, in this case, vocabulary mastery for sports students. Only a small percentage of students are able to answer questions about examples of nouns (Noun) by mentioning some words such as: table, pen, chair, pencil. This is far from the expectation because for the level of the second semester students who have gone through elementary, middle and high school level of education they should have basic knowledge of English or have been able to communicate well in oral and written language in English. This is then analyzed by researchers starting from the learning module as the main media or the main source for students to get material other than lecturers. So a needs analysis of vocabulary mastery for sports students is something that can attract their interest or something that is closely related to their world (sports).

Then in the third stage of the ADDIE model according to Prawiradilaga (2009), namely Development. Here the researcher plays a role in making and modifying teaching materials or in other words at this stage the researcher focuses on choosing activities, determining methods, learning media and learning strategies). Where the main goal at this stage is to revise the teaching material and choose the best media, namely the website www.goal.com so that it can arouse the motivation of sports students in learning English so that their vocabulary mastery increases. In this section students are introduced to the www.goal.com website in the teaching and learning process. Lecturers combine the material in the professional English learning module with the vocabulary on the website. Here researchers and lecturers discuss what methods are most suitable for motivating students to learn and improve their vocabulary mastery. In addition, researchers and lecturers also choose articles on the 
website www.goal.com that are in accordance with the themes of the unit in the learning module for sports students. After selecting several methods and making learning plans, researchers and lecturers continue to the fourth, namely implementation.

At this stage of implementation students are initially not enthusiastic in paying attention to the in focus screen that is connected to the website www.goal.com. During 1 meeting there were no significant changes in the teaching and learning process using the website www.goal.com. Sports students seemed not very enthusiastic in seeing sports articles on the website and it was still very difficult to find nouns in the article. In the second meeting, the lecturer replaced the teaching method that involved the website www.goal.com by reviewing prior knowledge about the noun (Noun) with a singular and plural form both in the form of definitions and functions and their use known by sports student.

Then the lecturer again straightened the understanding of the sports students about the theme of the day's learning, then the lecturer presented the website www.goal.com by choosing a hot issue theme for sports students such as championship trophies, premier league or soccer player transfers. Furthermore sports students are assigned to search for as many singular and plural nouns as possible which can be found in the article. At this meeting the students began to pay close attention to the contents of the ball article on the www.goal.com website to look for singular and plural forms of nouns, even though the results were not optimal because the nouns they got were still few. On the other hand, in terms of motivation, it has increased greatly because they have shown a significant increase in interest.

At the 3rd meeting the researchers changed the learning method by dividing sports students into small groups (Small Group Discussion) with the aim of more effective teaching and learning activities. Learning material is continued on the theme of nouns (Noun) in the form of Countable and Uncountable. At the core activity the lecturer divides students into small groups of 5 people. Then the lecturers again reviewed their prior knowledge about the subject of the language and then guided it by discussing the material in the module. After they understand the concepts of countable and 
uncountable noun, then the lecturer displays articles on the website www.goal.com. Then the lecturer gives the task to look for words related to the theme in the article.

At this meeting the classroom situation became more alive because students discussed with each other's groups. Students with a better level of understanding help students who have lower abilities. In addition, the lecturer also gave rewards to groups who managed to collect 15 nouns in 20 minutes. This further increases students' learning motivation in understanding the themes of learning and completing tasks given by the lecturer.

Based on observations from several meetings in the class conducted by researchers above, it can be concluded that in order to increase student motivation to learn sports and mastery of English vocabulary there needs to be some development carried out by lecturers in teaching material. This can be adjusted to the characteristics of each student, as in this study, namely developing a module by combining learning and the website www.goal.com, making small group discussions, making rewards. The implications of the tasks done by students will be the researchers develop into textbooks in collaboration with English lecturers.

Last is the evaluation stage which is the stage of learning efficiency and effectiveness measured through research activities in the form of product validity or formative tests. In this study, it was seen that the increase in mastery of the vocabulary of sports students using an instructional model involving the www.goal.com website was the average value in the pre-test 55.4 while the post-test value was 74.3. From the results of the formative tests that focus on mastery of vocabulary, it can be concluded that the results of the evaluation of the instructional model involving the website www.goal.com for sports students at the University of Dehasen Bengkulu are included into significant category. 


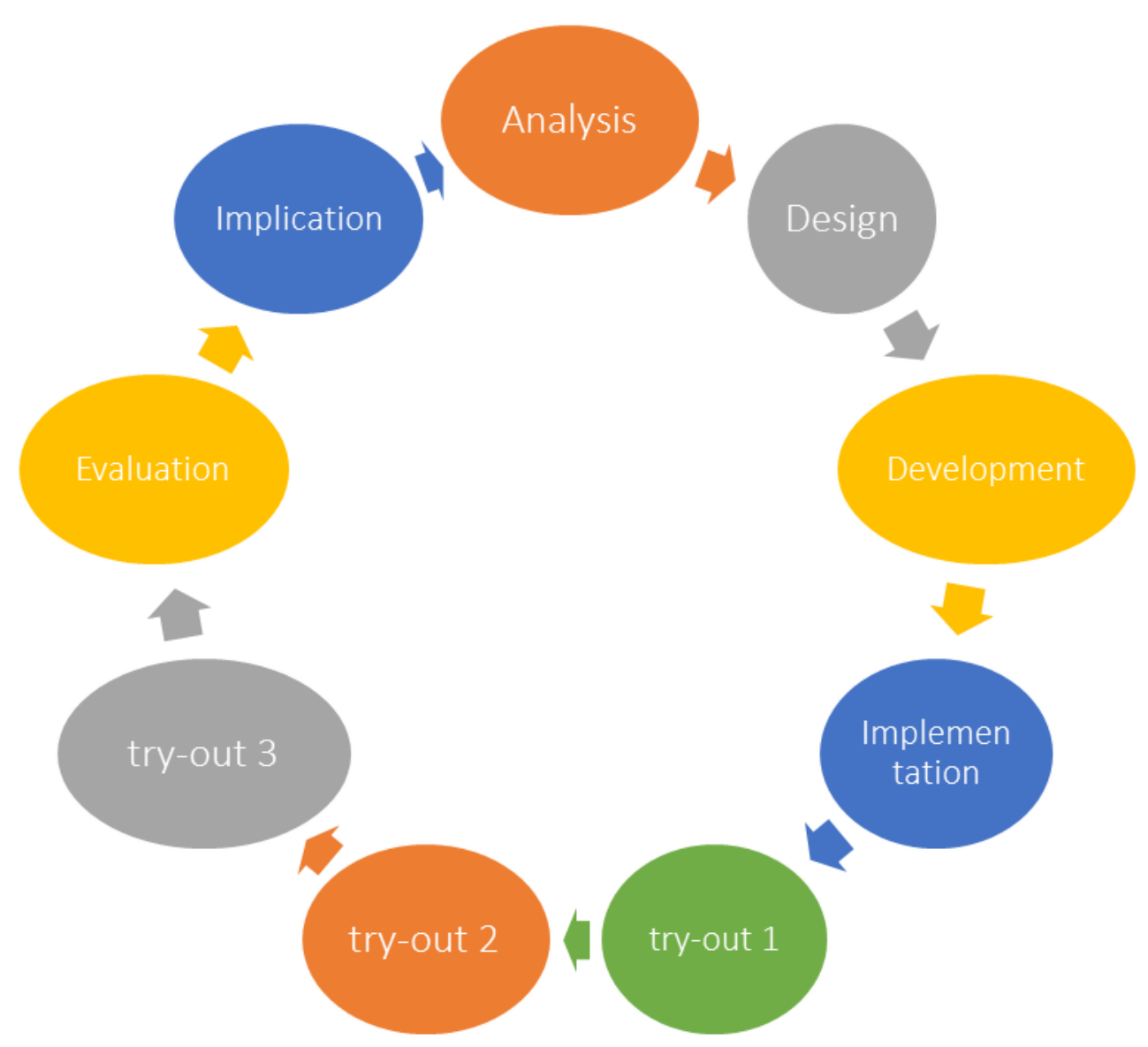

Figure 2. Instructional Model's Development

\section{CONCLUSION}

From the results it can be concluded that with the instructional model development of English through the website www.goal.com there is an improvement both in terms of learning motivation and vocabulary mastery of sports students at Dehasen University, Bengkulu. Therefore it is expected there is the development or modification of teaching materials / modules for sports students in next semester.

\section{REFERENCES}

Butcher, Christopher., Clara Davies, and Melissa Highton. (2006). Module Outline to Effective Teaching. New York: Routledge.

Dick, W and Carey, L. (2005). The Sistematic Desain of Instruktional. Boston : Allyn and Bacon. 
Kitao, K., and Kitao, S.K. (2009). Selecting and Developing Teaching/Learning Materials. Available from http://iteslj.org/articles/kitao-materials.html

Latif, M. A. (2012). Research Methods on Language Learning (An Intriduction). Malang: UM Press,

Marzano dan Jerrold, E. Kemp. (1992). Design Effective Instruction. New York: John Wiley and Sons.

Prawiradilaga, Dewi Salma. (2009). Prinsip Desain Pembelajaran. Yogyakarta:

Kencana Prenada Media Group.

Sanjaya, Wina. (2005). Kurikulum dan Pembelajaran. Jakarta: Prenada Media Group.

Sugiyono. (2016). Metode Penelitian Kuantitatif, Kualitatif dan R\&D. Bandung: PT Alfabet.

Tusino and Dewi, Puspa. (2016). Pengembangan Model Pembelajaran berbasis Intelerasi dalam Pembelajaran Bahasa Inggris untuk Meningkatkan Kecakapan Hidup. Jurnal Pendidikan Surya Edukasi (JPSE), 2(2), p.36,2541-4070. Retrieved from http://ejournal.umpwr.ac.id/index.php/surya/article/view/3463

Tomlinson, B. (2011). Materials Development in Language Teaching. United Kingdom: Cambridge University Press. 